\title{
A Letter's Importance: The Spelling of Daka(h) (Deut. 23:2) and the Broadening of Western Sephardic Rabbinic Culture
}

\author{
David Sclar*
}

On 5 February 1744 (22 Shevat 5504), David Franco Mendes, a young Portuguese Jew drawn to the study of the Hebrew language, wrote to the Italian poet and kabbalist Moses Hayim Luzzatto, who had recently emigrated to Acre after spending the previous eight years in Amsterdam. ${ }^{1}$ In the letter, Franco Mendes explained to his literary mentor ${ }^{2}$ that he had encountered a challenge to Portuguese religious and cultural sensibilities: a fellow Sephardi had purchased a Torah scroll from an Ashkenazic man, only to discover later that the word daka in Deuteronomy 23:2 was spelled with a heh (דכה) rather than with an alef (דכא) as dictated by community tradition. Franco Mendes, and presumably the Portuguese rabbinate, was unsure if Sephardim could use the scroll for ritual purposes. He apparently hoped that Luzzatto, a native of Padua, knew of similar issues of cultural conflict and halakhic resolution in the Italian Peninsula.

Seventeen years later, Moses Israel, a long-standing scholar in the Ets Haim yeshiva and former colleague of Luzzatto, published a ruling (pesak) in the

* Thanks to Jesse Abelman, Edward Fram, Matt Goldish, Jordan Penkower, and Pinchas Roth for their insight and helpful suggestions. I am grateful to Rachel Boertjens, Emile Schrijver, and Heide Warncke for assistance, and to the Mahamad of the Portuguese Jewish community in Amsterdam for permission to peruse their collection of Torah scrolls. Special thanks to Onno Voitus van Hamme, Project Researcher at the Jewish Historical Museum, for spending hours with me rolling scrolls in search of a single letter. I dedicate this article to my father, Abe Sclar, whose interest in the spelling of $d a k a(h)$ and similar curiosities sparked my love for historical minutia and the endlessness of knowledge.

1 Amsterdam, Ets Haim/Montezinos Livraria (hereafter EH), 47B3, p. 38 . On Luzzatto in Amsterdam, see David Sclar, "Adaptation and Acceptance: Moses Hayim Luzzatto's Sojourn in Amsterdam among Portuguese Jews," Association for Jewish Studies Review 40, no. 2 (November 2016): $335^{-5} 8$.

2 Nearly four decades later, Franco Mendes described Luzzatto as his teacher of all things poetic; see Moses Hayim Luzzatto, Derekh Hokhmah (Amsterdam, 1783), fol. 5v, and Irene E. Zwiep, “An Echo of Lofty Mountains: David Franco Mendes, a European Intellectual," Studia Rosenthaliana 3 , no. 2 (2001): 293.

(C) DAVID SCLAR, 2019 | DOI:10.1163/9789004392489_016

This is an open access chapter distributed under the terms of the prevailing CC-BY-NC License at the time of publication. 
community's Hebrew legal periodical, Peri Ets Hayim (Fruit of the Tree of Life), on an inverse case. ${ }^{3}$ An Ashkenazic man was publicly reading the Torah for a Sephardic congregation when he noticed that daka was spelled with a heh (דכה) rather than with the alef (דכא) he expected. He stopped reading and requested a different scroll, assuming he had discovered a singular mistake and that he could continue the ritual recitation from another Torah. The congregation rejected the man's request, stating that the word was spelled according to Sephardic tradition. The case hinged on whether the man could continue reading for the congregation despite the variant spelling that he assumed disqualified the scroll's suitability for himself and for Ashkenazim in general.

At first glance, Franco Mendes's 1744 letter and Israel's 1761 pesak contradict one another, with each claiming contrasting customs for the same Portuguese community in Amsterdam. Although the divergence hinged on a mere letter, the spiritual and cultural significance was high. Religious conviction required Torah scrolls, believed to be written manifestations of divine will, to match tradition. Inaccuracy in a scroll, or even an inadvertent slip of the pen that deformed a letter, disqualified the object for ritual use. Rabbinic scholars had been debating spelling and pronunciation for centuries, and as juxtaposed sources, Franco Mendes and Israel could appear to represent a local disagreement.

In fact, each author's words expressed Portuguese custom at the time of their respective compositions. A deeper view of the documents, in tandem with the community's surviving Torah scrolls from the period, reveals a historical development in which Portuguese Jewry altered its custom in imitation of contemporary rabbinic norms. That change reflected a transformation in Portuguese Jewry's socio-religious outlook. Sephardim and Ashkenazim in Amsterdam had long existed side by side but not as an integrated cultural body. The cases described by Franco Mendes and Israel indicate that in the mid-eighteenth century sufficient intimacy existed to exchange precious ritual objects and to pray together, though with some degree of religious and cultural discord.

This article explores some ramifications of and reactions to that conflict. Following a short section on Peri Ets Hayim and Israel's activity in the Portuguese yeshiva, I analyze Israel's rich pesak and the context in which Western Sephardim modified ritual in a small but meaningful way. Although

3 EH 4 Fin, Peri Ets Hayim (Amsterdam: Proops, 1761), ff. 117v-119r; for a synopsis, see Menko Max Hirsch, Frucht vom Baum des Lebens, Ozer peroth Ez Chajim (Berlin-Antwerp: [Soncino-Gesellschaft der Freunde des Jüdischen Buches], 1936), no. 407. A manuscript version, probably prepared for publication, is extant (University of Amsterdam, Bibliotheca Rosenthaliana, HS Ros. 579) (Fig. 15.1). Israel concluded the text with a chronogram that decodes to January 1761 . 
Luzzatto's reply is not extant, ${ }^{4}$ Israel's text amply illuminates the development of Portuguese religious culture in the eighteenth century. The final section addresses the variant spellings of $d a k a$, and, utilizing Torah scrolls in the possession of Amsterdam's Sephardic community, links and resolves the discrepancy between Franco Mendes and Israel. Elucidating the spiritual development, and its presentation in Israel's pesak, I argue that increased intellectual and social engagement with Ashkenazic culture in the eighteenth century broadened Portuguese rabbinic culture and eroded existing sentiments of communal exclusivity. Moreover, changing the spelling of daka signified deeper engagement with larger Jewish trends, suggesting a modernization through tradition that marked a new phase in the history of Portuguese Jewry. ${ }^{5}$

\section{Peri Ets Hayim}

In 1728, David Israel Athias and Isaac Hayim Abendana de Britto became cochief rabbis of Amsterdam's Portuguese Jewish community, replacing the recently deceased Hakham Salomon Ayllion. Whereas Ayllion had been drawn to Kabbalah, adhering to Sabbatianism and at one point publicly celebrating the arrival in Amsterdam of an accused heretic, ${ }^{6}$ Athias and Abendana de Britto advocated intensive rabbinic study. During their decades-long tenures, the Ets Haim yeshiva deepened its Talmudic and halakhic curricula and trained students to serve as rabbis in an expanding Western Sephardic diaspora. Members of the yeshiva manifested their rabbinic aspirations in Peri Ets Hayim, a serial publication of halakhic rulings on issues broadly relevant to the community. Under the direction of Abendana de Britto, who served as rosh yeshiva of the Ets Haim, teachers and advanced students (many of whom became the next generation's instructors) produced approximately four hundred pesakim in the periodical. Even as the community faced financial difficulties, brought on by an economic downturn and increasing numbers of indigent Jews in Amsterdam, the Ets Haim yeshiva remained committed to the costly production of twelve

4 There is no indication that Luzzatto wrote a reply or even received Franco Mendes's letter.

5 On this interplay between tradition and modernity, see David Sclar, "Blending Tradition and Modernity: The Growth of the Ets Haim Library in the 18th Century," in Tradition \& Modernity in Ets Haim, ed. David Wertheim (Amsterdam: Menasseh Ben Israel Institute and the University of Amsterdam, 2017), 19-33, 38-39.

6 On the heresy of Nehemiah Hiya Hayun and his activity in Amsterdam, see Elisheva Carlebach, Pursuit of Heresy: Rabbi Moses Hagiz and the Sabbatian Controversies (New York: Columbia University Press, 1990), chap. 4. 
or thirteen pesakim per year. ${ }^{7}$ Nearly one thousand in total were produced by the time the enterprise ceased in the second decade of the nineteenth century. 8

Broadly, Peri Ets Hayim emulated contemporary collections of responsa. The genre had long been crucial to the halakhic process and rabbinic culture, circulating first in manuscript and then in print. Responsa literature flourished in the middle of the eighteenth century, as the sons and students of living or recently deceased scholars brought writings of practical halakha to press, solidifying in book form the activity of large networks of rabbinic thinkers. ${ }^{9}$ In contrast to the brevity of medieval examples, early modern responsa appeared as essays displaying authors' expansive knowledge and intellectual prowess. Scholars frequently fabricated "questions" themselves and responded with erudition and force in the hopes of establishing their voices as authoritative. ${ }^{10}$

Despite mirroring these trends, Peri Ets Hayim stood uniquely as a multigenerational body of work initiated by an educational system. Ets Haim leadership standardized the publication process, ${ }^{11}$ compelling authors to follow a given format in composing their essays. ${ }^{2}$ Pesakim frequently began with a

7 David Sclar, "Books in the Ets Haim Yeshiva: Acquisition, Publishing, and a Community of Scholarship in Eighteenth-Century Amsterdam," Jewish History 30, no. 3 (2016): 224-26.

8 Most published products appeared in two-columns, between forty and forty-four lines per page, and consisted of at least three thousand words.

9 For instance, Ezekiel Katzenellenbogen's Keneset Yehezkel (Altona, 1732), Isaiah Bassan's Lahme Todah (Venice, 1741), Jacob Poppers's Shav Ya'akov (Frankfurt, 1742), Joseph Ergas' Divre Yosef (Livorno, 1742), and Samson Morpurgo's Shemesh Tsedakah (Venice, 1743), as well as Isaac Lampronti's halakhic encyclopedia Pahad Yitshak (Venice, 1750), which integrated responsa from contemporary scholars.

10 On responsa literature in the early modern period, see Matt Goldish, Jewish Questions: Responsa on Sephardic Life in the Early Modern Period (Princeton, NJ: Princeton University Press, 2008), xlviii-lv; Edward Fram, Ideals Face Reality: Jewish Law and Life in Poland 1550-1655 (Cincinnati: Hebrew Union College Press, 1997), 7-10; and Jay R. Berkovitz, "The Persona of a Poseq: Law and Self-Fashioning in Seventeenth-Century Ashkenaz," Modern Judaism 32, no. 3 (2012): 251-69. On historiographical use of responsa, see Jacob Katz, The "Shabbes Goy": A Study in Halakhic Flexibility, trans. Yoel Lerner (Philadelphia: Jewish Publication Society, 1989); and Haym Soloveitchik, The Use of Responsa as an Historical Source: A Methodological Introduction [Hebrew] (Jerusalem: The Shazar Center and The Hebrew University of Jerusalem, 1990).

11 Likewise, rabbis and students followed a uniform practice in producing sermons. Each of the seven rabbinic talks celebrating the dedication of the Esnoga in 1675, for instance, began with Biblical and Mishnaic quotations before delving into a lengthy exposition of the texts and the glory of the community; see Sermoes que pregaraõ os doctos ingenios do K.K. de Talmud Torah, desta cidade de Amsterdam, no alegre estreamento, \& publica celebridade da Esnoga que se consagrou a Deos (Amsterdam: David de Castro Tartaz, 1675).

12 For an example of how earlier responsa were utilized for a question in Peri Ets Hayim, see Shmuel Glick, ed., Seride Teshuvot of the Ottoman Empire Sages from the Cairo Genizah 
narrative and invariably concluded with a chronogram referring to both the year and week during which it had been composed. ${ }^{13}$ Authors submitted their work to the rosh yeshiva for review, after which a scribe or the author himself rewrote the full text legibly for submission to a print shop (Fig. 15.1).

The publications generally dealt with issues surrounding property, interest, charity, marriage, and additional topics relevant to Portuguese communities engaged in mercantilism and concerned with kinship. Pesakim frequently refer to wealthy men, owners of multiple houses, and individuals engaged in overseas ventures, though it is unlikely that laymen studied the texts or bothered to align business practices with halakha. ${ }^{14}$ Instead the emphasis on applied Jewish law reflected the Mahamad's plan to train communal rabbis and strengthen the bonds of religious segments of Portuguese society.

The extent of this endeavor's success requires further research, but it is nevertheless clear that Peri Ets Hayim served as the intellectual fruit of an elite within the Ets Haim's highest class. Not all students found on the rolls of the Medras Grande submitted halakhic essays. Each generation seems to have had few men interested in, capable of, or tasked with submitting pesakim. In the early decades of the serial's publication, Abraham da Costa Abendana, Aaron Ledesma, Samuel Acatan, David Meldola, Jacob Bassan, and a handful of others-most of whom taught in the Ets Haim or became communal rabbis in the Portuguese diaspora-published dozens of rulings between them. Authors were expected to utilize a wide range of sources, including the Babylonian and Jerusalem Talmuds and their commentaries, halakhic codes, and responsa literature from both Sephardic and Ashkenazic authorities. The latter sources stood not only as exemplars for their own work, but also indicated that the Ets Haim had moved from its origins as a Portuguese seminary, focusing on Bible and literature, to a yeshiva that sought to make itself first and foremost rabbinic.

Moses Israel's long career in the Ets Haim exemplified the activity of the Portuguese religious elite in the eighteenth century. By the time he issued his pesak on the spelling of daka in 1761, Israel had been a fixture of the Ets

Collection of the Cambridge University Library [Hebrew] (Jerusalem: The Schocken Institute for Jewish Research of the Jewish Theological Seminary of America, 2013), 39-41.

13 Chronograms were ubiquitous in medieval and early modern Jewish culture, but authors generally stated a day and date explicitly, leaving the year to be decoded from a quoted verse. In Peri Ets Hayim, authors were tasked with drawing a verse from that week's Torah pericope, indicating (less overtly) the date of authorship.

14 On the latter issue, see Matt Goldish, "Rabbi Jacob Sasportas: Defender of Tradition in an Age of Change," Master's thesis, Hebrew University of Jerusalem, 1990, chap. 3. 


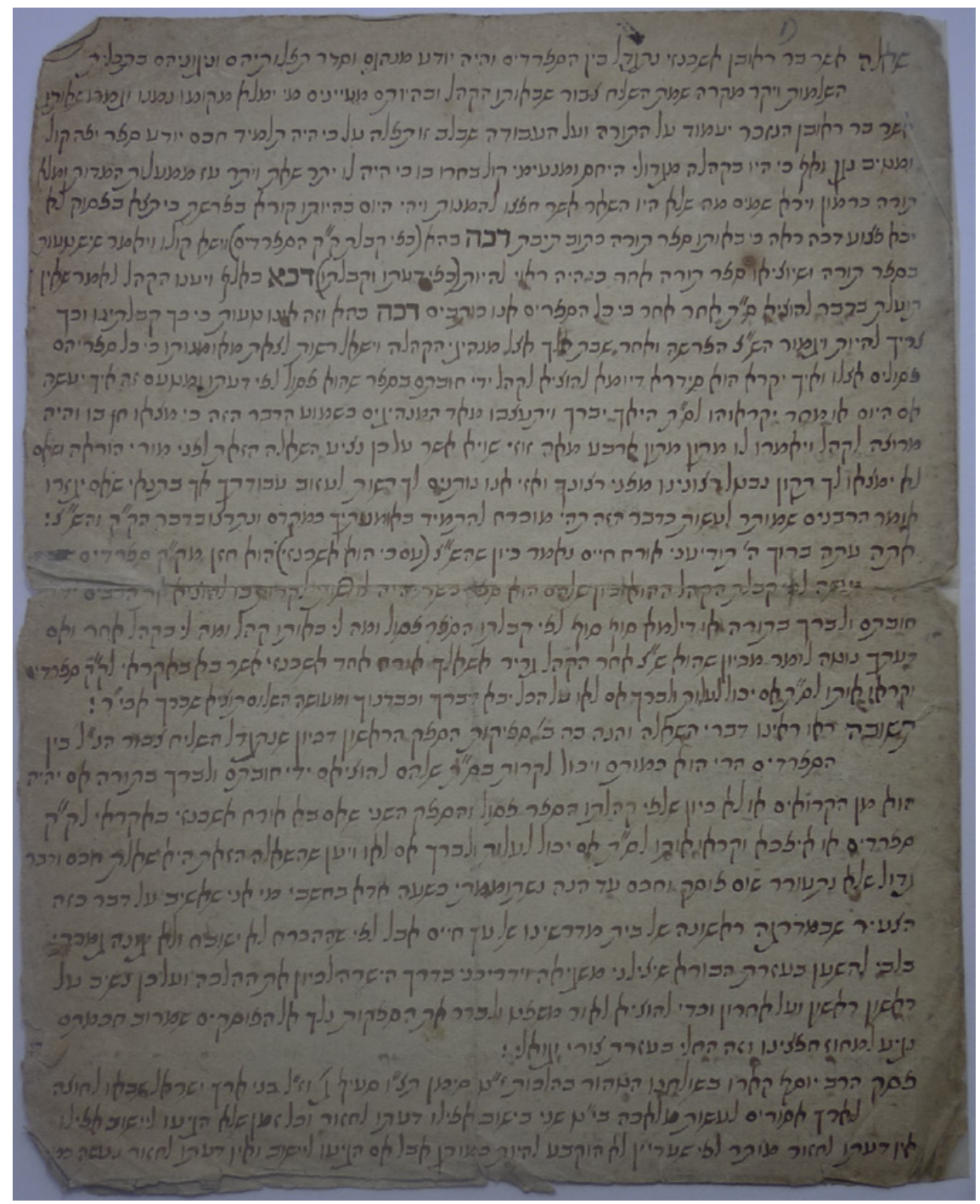

FIGURE 15.1 Pesak written by Moses Israel, Bibliotheca Rosenthaliana, Special Collections of the University of Amsterdam, HS Ros. 579 
Haim for three decades. ${ }^{15}$ He regularly earned a stipend (aspaca) to study in the Medras Grande, and, as early as January 1733, he had been counted among a select group of students additionally funded by the privately-endowed but publicly administered yeshiva, Emet Le Jahacob. ${ }^{16}$ In 1742 , he worked with his Ets Haim colleague, David Meldola, to edit a primer for the study of Talmud by Moses Hayim Luzzatto. ${ }^{17}$ Israel's work on the book demonstrated his proficiency in Talmud and rabbinic literature more broadly, as well as his closeness to Luzzatto, a kabbalist, and to Meldola, the most prolific Western Sephardic scholar of his generation. After two decades of study in the highest class of the Portuguese yeshiva, Israel was well-positioned to produce numerous and diverse halakhic essays. Between 1754 and 1780, he published fifty-seven pesakim on cases of marriage, business, and ritual, including several concerning Torah scrolls.

Although most cases circulated in Peri Ets Hayim were fabricated to facilitate intellectual exercise, questions invariably drew on contemporary Portuguese experience and reflected authors' social and cultural milieu. In his erudite pesak on the spelling of daka, Israel sought to guide Portuguese Jews wrestling with their identity amid increased interaction with Ashkenazic Jews. He conveyed evolving attitudes toward tradition and signified how societal progress initiated new halakhic questions. Despite the legal premise, emotion and personal experience featured prominently in Israel's ruling, and he exhibited both originality and sensitivity in his attempt to steer a religious culture challenged by ritual disparity.

Israel's four-page essay commences with a narrative about a man named Asher bar Reuben Ashkenazi, who, despite the heritage evoked by his surname, had been raised among Sephardic Jews (Fig. 15.2). His age and origin are not detailed, but the text informs the reader that the man came to know Sephardic customs, prayers, and songs as if they were his own. At some point

\footnotetext{
15 Moses Israel's biography has yet to be pieced together; several other men with the same surname studied in the Ets Haim during his tenure, including Abraham, Aharon, Isaac, and Samuel (Archive of the Portuguese-Jewish Community, Stadsarchief Amsterdam [hereafter, SAA] 334, no. 1189, passim).

16 SAA 334, no. 1053, p. 43. Emet Le Jahacob and Oel Jahacob were founded by Jacob Pereira in the late seventeenth century, with numerous men, including the chief rabbis, receiving stipends, but they did not function as separate yeshivot.

17 Derekh Tevunot (Amsterdam: Joseph Dayan, 1742).
} 


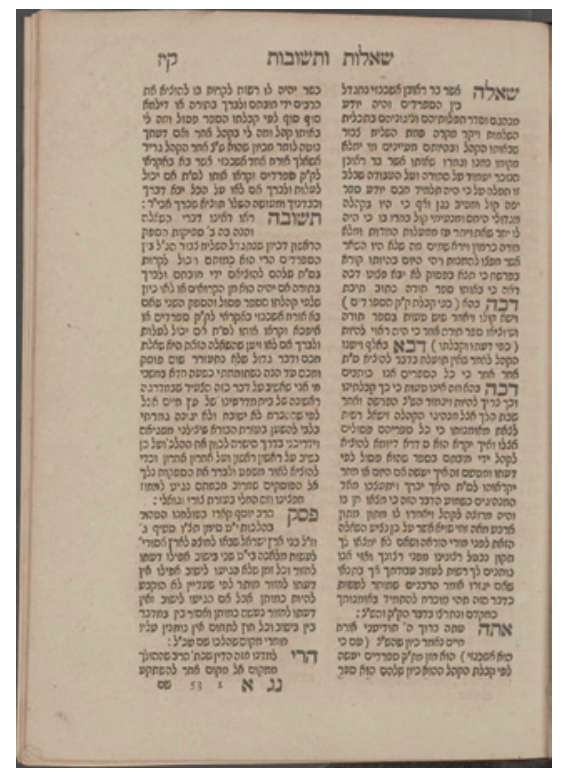

FIGURE 15.2

Pesak written by Moses Israel, Peri Ets Hayim (Amsterdam: Proops, 1761),

$\mathrm{EH} 4 \mathrm{~F} 11$, fol. $117 \mathrm{r}$

in adulthood, his community was left without a prayer leader when the local cantor suddenly died. The congregation turned to Ashkenazi, whom they regarded as a well-informed scholar with a pleasing voice and musical ability. ${ }^{18}$ Although prestigious members of the synagogue objected bitterly, apparently because of the man's ethnicity, Israel's "questioner" explained that most people in the community considered Ashkenazi's dignity, humility, and fear of Heaven to be stellar and of supreme importance.

One day while publicly reciting the Torah portion Ki Tetse, Ashkenazi noticed that the word daka in Deuteronomy 23:2 was spelled with a heh. ${ }^{19} \mathrm{He}$ stopped midsentence to announce that he had found an error in the scrollthe word should have ended with an alef, he claimed - and called for another scroll to be taken from the ark. Despite the congregation's tradition of spelling the word with a heh, the new cantor argued that he, as a man of Ashkenazic descent, was required to follow his own ancestral tradition. The congregation responded that there was no use in taking out a different scroll, because, "as all Sephardim know," the word was appropriately spelled. They informed him

18 היה תלמיד חכם יודע ספר יפה קול ומטיב נגן

19 Israel did not comment on the meaning of the text itself, even though it inspired an unrelated case in Hamburg-Altona; see Maoz Kahana, "An Esoteric Path to Modernity: Rabbi Jacob Emden's Alchemical Quest," Journal of Modern Jewish Studies 12, no. 2 (2013): 253-75. 
that all their scrolls were written likewise, and insisted that Ashkenazi finish the reading.

After the Sabbath, Israel's narrative continues, Ashkenazi asked the community's lay leadership for permission to correct the scrolls. He argued that the current spelling invalidated the Torah scrolls for Ashkenazic Jews, undercutting his ability to fulfill the ritual reading on behalf of the community. In addition, more personally, Ashkenazi questioned how he could recite customary blessings over the scrolls in defiance of the injunction against uttering benedictions over defective ritual items. Hoping to convey the gravity of the exchange, the "questioner" stated that Ashkenazi's statement saddened the leadership, who, like most communal members, valued Ashkenazi's services. They decided to submit the question to competent halakhic authorities: if the latter sided with Ashkenazi, he would be permitted to abandon his work with the community (amending the scrolls was not an option); if they rejected his assessment he would be obligated to abide by the congregation's tradition.

Placing himself in the literary role of arbiter, Israel began his "answer" by articulating two interconnected dilemmas. Was Ashkenazi permitted to read from the congregation's Torah scrolls if it meant he would contradict his own tradition, and, extrapolating more broadly, could Ashkenazim visiting Sephardic congregations ascend to the Torah and recite blessings over a scroll that included a variant spelling? The former inquiry—and the narrative about an Ashkenazic man raised in a Sephardic community retaining his heritage but serving as cantor-seems to have been a deliberate setup for the latter. There is no evidence of an early modern Portuguese community employing an Ashkenazic cantor or sanctioning the adoption of Ashkenazic children. However, with increased social and geographic mobility in the eighteenth century, Jews of diverse origins in Western Europe regularly encountered co-religionist rites that differed from their own. In the 1730s, Ezekiel Katzenellenbogen recorded a query from an Ashkenazic man living (and presumably working) in a Sephardic home in Hamburg. ${ }^{20}$ On Hanukkah, the questioner had attempted to light a menorah in keeping with Ashkenazic custom, only to be rebuffed by his landlord who insisted, based on his own Sephardic custom, that he as head of the household should perform the commandment for all occupants. ${ }^{21}$ Though variations within Jewish religious

$20 \quad$ Keneset Yehezkel (Altona, 1732), no. 17. Thanks to Yigal Sklarin, who analyzed this source in an unpublished research paper for a graduate course at Yeshiva University.

21 Katzenellenbogen ruled in favor of the Ashkenazic man, arguing that the assumption of the owner of the house-that he reserved the right to impose his custom based on a halakhic concept prohibiting factionalism (לא תתגודדו)-was both unfounded and, considering Sephardim arrived in German lands long after Ashkenazim, quite the inverse. 
practice are as old as tradition itself, conflict over ritual and identity intensified in places and times of demographic change.

Still, contemporary responsa are not replete with questions stimulated by inter-communal discord, and Israel's pesak staked a claim in uncharted territory. Addressing both his fictional and actual audiences in a dual role as the narrative's judge and essay's author, Israel remarked that Asher bar Reuben Ashkenazi's query "has not previously arisen among our legalists and sages. I was astounded to consider my position as [the first to] reply to this, a mere juvenile in the first class of our Midrash in the Ets Haim. Out of necessity, not praise or distress, I resolved to lean on the help of the Creator to save me from errors and lead me on the straight path to determine the halakha."22 The observation, in the voice of a humble judge compelled to adjudicate, demonstrated Israel's self-awareness and confidence. With an excellent rabbinic library at his disposal, he correctly concluded that the halakhic corpus recorded no precedent and embarked upon solving a new issue of communal importance.

Ultimately, Israel ruled in the affirmative in both cases: the mythical Ashkenazi could continue to serve as cantor, and Ashkenazim praying with Sephardim (and vice versa) could recite blessings over scrolls with spellings that ran contrary to their own traditions. His argument rested on several halakhic sources, particularly rulings that elevated local tradition above an individual's personal custom (minhag ha-makom). For instance, the Shulhan Arukh codified a law whereby Jews from Palestine who traveled to communities outside the Holy Land were restricted from certain activity on the second day of a festival (yom tov sheni). ${ }^{23}$ (Jews in the Holy Land observe festivals for just one day, in contrast to the two days expected of Jews outside the Land.) By the early modern period, with increasing travel particularly of emissaries seeking alms, ${ }^{24}$ halakhic authorities insisted that Jews visiting communities abroad refrain from open displays of action prohibited to their hosts. Likewise, itinerant rabbis who assumed rabbinic posts were required to follow local traditions rather than their own. ${ }^{25}$ This proved relevant in the Italian Peninsula, where scholars and teachers often roamed from town to town serving congregations of varying ethnicities, ${ }^{26}$ and in Amsterdam itself, where Ashkenazic rabbis Uri

\footnotetext{
22 EH 4 Fi1, Peri Ets Hayim, fol. $117 \mathrm{v}$.

23 Shulhan Arukh, Orah Hayim, Hilkhot Yom Tov, § 496:3.

24 See Matthias B. Lehmann, Emissaries from the Holy Land: The Sephardic Diaspora and the Practice of Pan-Judaism in the Eighteenth Century (Stanford: Stanford University Press, 2014).

25 Arba'ah Turim, Orah Hayim, Hilkhot Pesah, 468.

26 On itinerant rabbis in Italian communities, see Robert Bonfil, Rabbis and Jewish Communities in Renaissance Italy, trans. Jonathan Chipman (Oxford: Littman Library of Jewish Civilization, 1990), 192-206.
} 
Phoebus Halevi and Saul Levi Mortera helped shape the Portuguese Jewish community in the seventeenth century.

Israel bolstered his argument with citations from Talmud tractates Hullin and Pesahim emphasizing the importance of adopting minhag ha-makom in public matters. He debated the issue of whether a visitor differs from a permanent resident, but concluded that the case of Asher bar Reuben Ashkenazi especially necessitated the adoption of community ritual. Raised among Sephardim, the imaginary Ashkenazi was, for all intents and purposes, "like them." Citing the seventeenth-century halakhist Hezekiah da Silva, Israel argued that visitors in general, let alone men in Ashkenazi's predicament, should abide by a given congregation's custom even if the city hosted synagogues operating otherwise. That is, the individual in question could not follow his own custom based on an assumption, true or not, that local Jews were aware and tolerant of alternative practices.

Consequently, Israel rejected the notion that Sephardim and Ashkenazim should or even could function separately and without regard for each other. He sought to preserve divergent traditions in conjunction with frequent crosscultural interaction, and, as such, advocated leniency in this previously unaddressed but socially significant halakhic matter. To support his approach, Israel cited Joseph Karo's reference to a Maimonides responsum permitting blessings over an invalid (pasul) Torah scroll, ${ }^{27}$ and otherwise promoted restraint with respect to faulty scrolls. As conveyed in the narrative, standard practice called for a new scroll to be brought from the ark in instances where a mistake was discovered. If noticed mid-aliyah, following the recitation of the blessing that customarily preceded a reading, the reader would continue where he had left off. Upon completion of that portion of text, the man called for the ali$y$ ah would recite the after-blessing but would not pronounce the first blessing anew. While the discovery of a mistake in the first scroll necessitated the use of a different scroll for the remaining sections of the Torah portion, it did not invalidate previous aliyot or their blessings. An error amid a scroll's 300,000 plus letters could go undetected for months, and it could not reasonably be assumed after the fact that previous readings and blessings had been made in vain. Thus, Israel concluded, an Ashkenazic visitor in a Sephardic community could receive an aliyah without concern for the spelling of daka, because a

27 Kesef Mishnah on Mishneh Torah, Sefer Ahavah, Hilkhot Sefer Torah 10:1. Karo states that Maimonides meant it only when no other scroll was available. Elsewhere, he ruled that a blessing may not be recited in such circumstances; see Shulhan Arukh, Orah Hayim, $\S 143: 2-3$. 
mere letter, so important in the moment of discovery, did not outweigh the importance of ritual practice that assumed the validity of any particular scroll.

In so ruling, Israel sought to establish a precedent for tolerant or permissive ritual interaction between the two ethnic groups. In Israel's telling, Asher bar Reuben Ashkenazi earned his position despite the objection of prominent members in the community, because the majority of the congregation cared less about his ethnicity than his ability. By including such an extraneous comment, irrelevant to the case at hand, Israel expressed his latent conviction that his own community should function likewise. For generations, Portuguese Jewry had lived largely independently from other Jewish societies, forming an identity as a distinct Nação ${ }^{28}$ From the community's inception in the early seventeenth century, communal rules governed social interaction between Sephardim and Ashkenazim, including in matters of education, poor relief, and marriage. Cultural differences contributed to and to some degree ensured communal separation, as Amsterdam's Portuguese Jews were typically wealthier, more cosmopolitan, and less religious than their Eastern European counterparts. Over decades, however, contact between varying ethnicities increased and distinctions lessened. Print shops in particular facilitated greater awareness and even collaboration between Amsterdam's Sephardic and Ashkenazic rabbinates. By the mid-eighteenth century, Ashkenazim (including Luzzatto) were formally permitted to study in the Ets Haim yeshiva, and documents point to Sephardim holding prayer services with their Eastern European coreligionists. ${ }^{29}$ To be sure, the Mahamad infrequently provided Ashkenazic students with stipends and habitually prevented diversity in the synagogue. Perhaps Israel's pesak gave voice to a silent majority objecting to longstanding inflexibility in the Esnoga. Likewise, as an integral member of the Ets Haim with ties to Amsterdam's Hebrew print shops and the city's Ashkenazic intellectual elite, Israel may have wanted to justify his own experience, or sought to motivate communal leadership to expand social and cultural horizons.

Regardless, as an authorized product of PeriEts Hayim, Israel's essay reflected some sort of official policy. His concluding statement suggests lay and rabbinic leadership felt it necessary to respond to entrenched Sephardic-Ashkenazic

28 See Jozeph Michman, "Between Sephardim and Ashkenazim in Amsterdam," [Hebrew] in The Sephardi and Oriental Jewish Heritage, ed. Issachar Ben-Ami (Jerusalem: Magnes Press, 1982), 135-49; Miriam Bodian, The Hebrews of the Portuguese Nation: Conversos and Community in Early Modern Amsterdam (Bloomington: Indiana University Press, 1997), 125-31; Yosef Kaplan, An Alternative Path to Modernity: The Sephardi Diaspora in Western Europe (Leiden: Brill, 2000), 78-107; and Daniel Swetschinski, Reluctant Cosmopolitans: The Portuguese Jews of Seventeenth-Century Amsterdam (London: Littman Library of Jewish Civilization, 200o), 187-96.

Sclar, "Books in the Ets Haim Yeshiva," 226-31. 
integration. "Today, there are places home only to Sephardic congregations, where they call Ashkenazim to the Torah who make the blessings," Israel remarked. "So too are there places home only to Ashkenazic congregations, where they call Sephardim to the Torah, and they recite the blessings. Let them [continue], for [today] there are no prophets or sons of prophets in Israel! It seems that God, in His mercy, will deliver us from error as we seek out His wondrous teachings. Amen." With Jews of varied backgrounds regularly praying together without concern for ritual discrepancy, Israel and his patrons evidently decided to sanction rather than challenge circumstances they had no power to alter. As we shall see, broadened religious and communal interests led to a ritual adaptation, making Israel's erudite pesak as much a proclamation about the narrative's social premise as it was an intellectual exercise.

\section{$3 \quad$ An Altered Letter}

David Franco Mendes's and Moses Israel's concerns over the spelling of daka pertained to a centuries-long process of establishing the Biblical text. Early rabbinic literature refers to the problem of variant readings, and medieval sources, most notably the writings of the masorah, embarked on efforts to determine correct readings. ${ }^{30}$ Scholars during the early modern period argued for the importance of fixing the text, frequently debating the importance of a single letter. Questions arose, for instance, as to whether the word sho'el (שאל) (Deut. 10:12) should retain a $v a v .{ }^{31}$ Foreshadowing Israel's pesak by more than a century, Nathan Nata Spira (1585-1633) argued that even though the word should be spelled without a $v a v$ it was acceptable to use the alternative if necessary. By the seventeenth and eighteenth centuries, several treatises on the intricacies of scribal practices had been written, including Meir Abulafia's Masoret Seyag la-Torah, Menahem Lonzano's Or Torah, and Jedidiah Norzi's Minhat Shai. In Israel's own community, Moses Gomez de Mesquita published a pesak on whether the divine name Elohim required a $v a v,{ }^{32}$ and Judah Piza, a colleague of Israel and Luzzatto in the 1740s, commented on issues related to continuing a ritual Torah reading if a scroll were found to be defective. ${ }^{33}$

Even as scholars and scribes resolved textual inconsistencies, the problem of how to spell daka persisted. During the medieval era, most Ashkenazic and

\footnotetext{
30 See B. Barry Levy, Fixing God's Torah: The Accuracy of the Hebrew Bible Text in Jewish Law (Oxford: Oxford University Press, 2001).

31 Ibid., 160-64. Including the letter would enable the verse to consist of one hundred letters.

$32 \quad \mathrm{EH} 4 \mathrm{~F} 8$, Peri Ets Hayim, fol. $163 \mathrm{r}$ (Hirsch, no. 66).

$33 \mathrm{EH}{ }_{4} \mathrm{~F}_{5}$, Peri Ets Hayim, fol. 116r (Hirsch, no. 278).
} 
Sephardic manuscripts had retained an alef, ${ }^{34}$ typified by the tenth-century Aleppo Codex and the eleventh-century Leningrad Codex. Sephardic luminaries, including Maimonides and David Kimhi, subsequently recorded an alef. .35 The propagation of Lonzano's Or Torah and Norzi's Minhat Shai in the early modern period, however, influenced many scribes to adopt a heh spelling. ${ }^{36}$ Communities, beginning in the Italian Peninsula and radiating outward, abandoned earlier traditions in favor of contemporary consensus. By the eighteenth century, the divergence had demarcated largely along ethniccultural-communal lines, with Sephardim usually ending daka with a heh and Ashkenazim commonly employing an alef.

In their respective writings from 1744 and 1761 , both Franco Mendes and Israel wrestled with the religious ramifications of this textual inconsistency. They concerned themselves with the permissibility of utilizing a scroll that ran contrary to their cultural norm. Had either been a scholar of Ashkenazic, Italian, Levantine, or North African origin, their juxtaposition would have gone no further than the general issue of what B. Barry Levy has called "fixing God's Torah." However, Franco Mendes and Israel lived simultaneously in the same community as part of the same educated elite. As descendants of conversos, Portuguese Jews had come to formulate their rabbinic tradition collectively and without direct connection to living practice. The unification of Amsterdam's Sephardic population in the 1630 s and the consolidation of power in the Mahamad ensured religious conformity and ritual homogeneity. As such, Franco Mendes and Israel did not and could not represent differing traditions or opinions within the community. Instead, Israel's pesak acted as an articulation of a deliberate cultural development.

A perusal of dozens of Torah scrolls owned by Amsterdam's Portuguese community reveals near uniform use of a heh in spelling daka. To be sure, the

34 See Mordechai Glatzer, "The Massora between East and West," [Hebrew] Pe'amim: Studies in Oriental Jewry 92 (2002): 168-69. On textual emendations in medieval Ashkenazic codices, see Yossi Peretz, "Darkhe Hagahat ha-Tekst ha-Mikra'e be-Kitve Yad Ashkenazim me-Yame ha-Benayim," Talele Orot 15 (2009): 19-34.

35 See Maimonides, Mishneh Torah, Sefer Ahavah, Hilkhot Sefer Torah 8:4, ed. Shabse Frankel (Jerusalem: Hotzaat Shabse Frankel Ltd., 2007) 2: 189; and David Kimhi, Sefer ha-Shorashim / Radicum Liber sive Hebraeum Bibliorum Lexicon (Berlin: Impensis G. Bethge, 1847), 71. Most printed editions of Maimonides' code do not record daka at all, though it does appear in Oxford, Ms. Huntingon 80. The disappearance of the word may reflect a decision by printers to avoid a discrepancy between Maimonides' text and popular practice.

36 See Jordan S. Penkower, Masorah and Text Criticism in the Early Modern Mediterranean: Moshe Ibn Zabara and Menahem De Lonzano (Jerusalem: Magnes Press, 2014); and Yosef Ofer, "Methods and Sources of Yedidya Shelomo Norzi in His Treatise Minhat Shay," Textus 24 (2009): 287-312. 


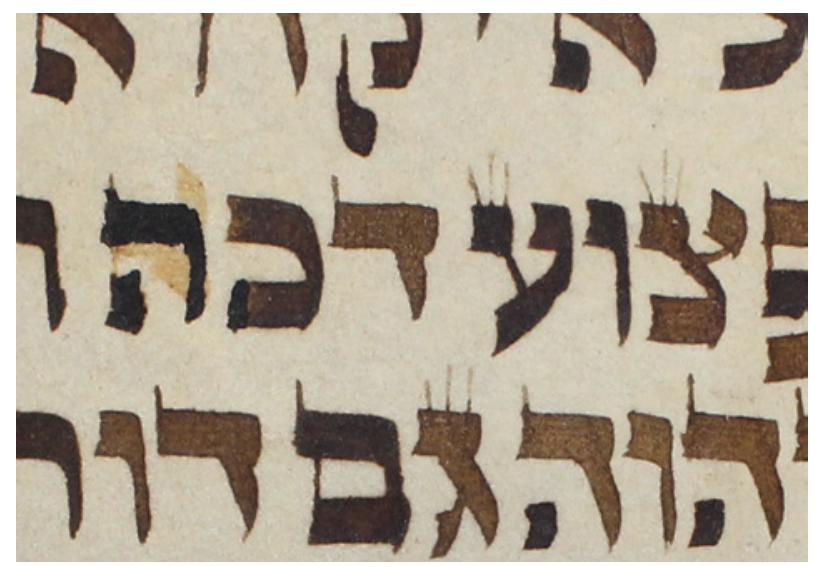

FIGURE 15.3 Ashkenazic script on klaf, produced in the seventeenth or eighteenth century, Portuguese Synagogue, Amsterdam, T45

seventeenth- and eighteenth-century scrolls consulted in this case study were not systematically written by the same scribe or according to the same specifications. The Mahamad and the Ets Haim yeshiva often employed scribes in the community to keep records in large bound codices, but they chose to acquire scrolls on an ad hoc basis rather than retain a regular scribe for ritual purposes. ${ }^{37}$ Both Sephardic and Ashkenazic scripts appear, and parchment varies from brown and pliable gevil to cream-colored and stiffened klaf. Textual layouts are also inconsistent, including the formats of notable passages such as the Song of the Sea, the Ten Commandments, and the Priestly Blessing.

Despite the disparate nature of the collection, three scrolls of different origins share a significant commonality: the word daka was originally penned with an alef before being changed to a heh in the eighteenth century. These Torah scrolls consist of: ${ }^{38}$ an Ashkenazic script on klaf written in the seventeenth or eighteenth century (Fig. 15.3);39 an eighteenth-century Sephardic script on klaf from Amsterdam or Hamburg (Fig. 15.4); ${ }^{40}$ and an eighteenthcentury Sephardic script on gevil (Fig. 15.5). ${ }^{41}$

37 Tirsah Levie Bernfeld has discovered references to men from Belgrade working, not very lucratively, as soferim in Amsterdam; see Tirtsah Levie Bernfeld, Poverty and Welfare among the Portuguese Jews in Early Modern Amsterdam (Oxford: Littman Library of Jewish Civilization, 2012), 36 .

38 Thanks to Jordan Penkower and Shlomo Zucker for confirming my assessment, and for providing more specific paleographic and codicological information.

39 Portuguese Synagogue, Amsterdam, $\mathrm{T}_{45}$.

40 Portuguese Synagogue, Amsterdam, T29.

41 Portuguese Synagogue, Amsterdam, T66. 


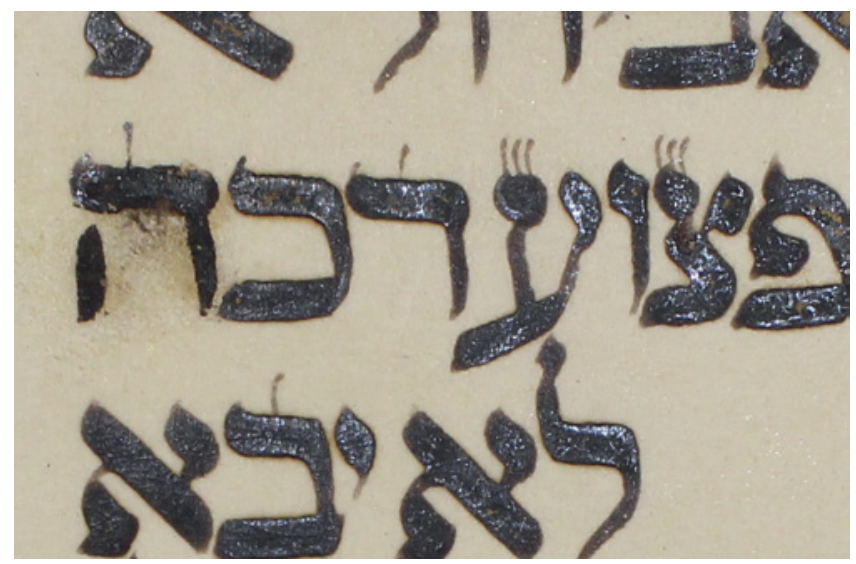

FIGURE 15.4 Sephardic script on klaf, probably produced in Amsterdam or Hamburg in the eighteenth century, Portuguese Synagogue, Amsterdam, T29

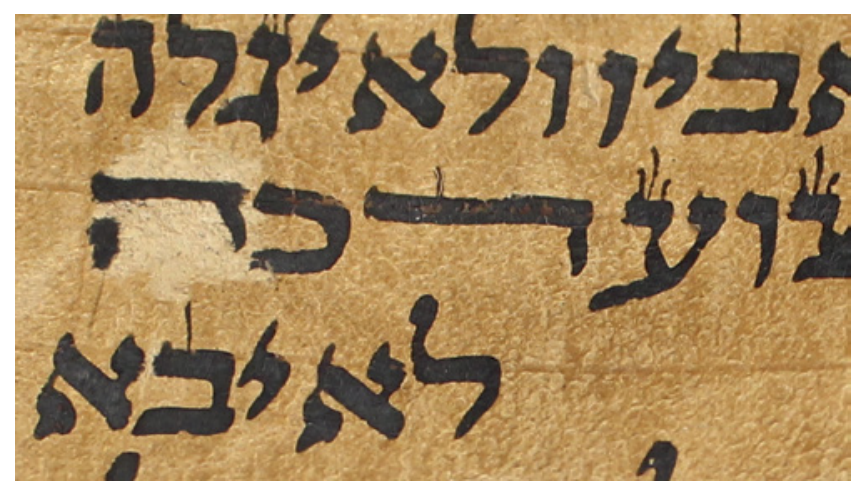

FIGURE 15.5 Sephardic script on gevil, produced in the eighteenth century, Portuguese Synagogue, Amsterdam, T66

In the first two, a faded alef is still visible under the heh, while the latter example shows the heh inscribed atop defaced parchment. The replacement letters appear contemporaneous with the original writing, indicating a calculated program to adopt the heh spelling.

Viewing the sources in tandem reveals that Franco Mendes's query echoed a medieval trend, Israel's pesak reflected modern developments, and the three corrected Torah scrolls (among others?) exemplified the transformation in custom. It is likely that Portuguese Jewry originally implemented the alef spelling based on the tradition of its first rabbi, Uriah Halevi (whose purported 
Torah scroll, still in the community's possession, displays daka with an alef), ${ }^{42}$ and early Sephardic authorities. Subsequent adoption of the heh spelling corresponded, not coincidentally, with the first printing of Norzi's Minhat Shai. Issued in Mantua in 1742, the influential work appeared just two years before Franco Mendes sent his letter to Luzzatto, while Abulafia's Masoret Seyag laTorah, a medieval work that similarly recorded daka with a heh, was published for the first time by a press in Florence in 1750. As I have shown elsewhere, Peri Ets Hayim coincided with an extensive program in the Ets Haim yeshiva to acquire texts from presses far and wide, integrating books from the Italian Peninsula and Central Europe within only a couple of years of printing. ${ }^{43}$ Advanced students in the Medras Grande immersed themselves in newly printed rabbinic texts, authored and edited their own, and pivoted their intellectual horizons toward Talmud, halakha, and cutting-edge rabbinics. In a Jewish culture of learning that regarded publication as supremely authoritative, ${ }^{44}$ Abulafia's and Norzi's shared contention that daka should be spelled with a heh took root and ultimately blossomed on the Portuguese tree of knowledge. That is, in a period of less than two decades, Amsterdam's Portuguese rabbinate absorbed the predominant Masoretic teachings then emanating from Hebrew print shops in Northern Italy, abandoned its earlier adopted custom in favor of contemporary norms, and publicized this development through the community's halakhic serial Peri Ets Hayim. 45

42 Portuguese Synagogue, Amsterdam, T57.

43 See Sclar, "Books in the Ets Haim Yeshiva," 220.

44 On the authority of print, see Fram, Ideals Face Reality, 6-7; and Elchanan Reiner, "Beyond the Realm of the Haskalah-Changing Learning Patterns in Jewish Traditional Society," Simon Dubnow Institute Yearbook 6 (2007): 123-133.

Although Peri Ets Hayim periodically included scholarship on Jews' most important ritual object, the sum amounted to less than one percent of the hundreds of halakhic essays produced during the mid-eighteenth century. Beyond the pesak discussed in this article, and the pesakim by Moses Gomez de Mesquita and Judah Piza mentioned above, Portuguese scholars addressed monetary values of Torah scrolls, as well as their importance to individuals, families, and community; see EH $4 \mathrm{~F} 9$, Peri Ets Hayim, fol. $257 \mathrm{r}$ (Hirsch, no. 94); EH 4 F11, Peri Ets Hayim, fol. 133r (Hirsch, no. 415); EH 4F12, Peri Ets Hayim, fol. 8r (Hirsch, no. 419); $\mathrm{EH}_{4} \mathrm{Fr}_{3}$, Peri Ets Hayim, fol. 4or (Hirsch, no. 503). In addition, in 1768, Israel published a pesak on the writing of Torah scrolls and phylacteries (EH $4 \mathrm{~F} 12$, Peri Ets Hayim, fol. 258 r [Hirsch, no. 485]). 
When viewed on a historical continuum, Franco Mendes's letter and Israel's pesak reflect a larger cultural issue. Apprehension over a Torah scroll's textual validity for one ethnic group but not another indicated that divergent customs, previously in contention only on the pages of halakhic codes, had led to tangible perplexity. Franco Mendes's 1744 letter to Luzzatto, a kabbalist and poet not known for staking claims in halakha, suggests scholars in the Ets Haim yeshiva felt unable to render a decision. Without Luzzatto's response, we can only surmise that Franco Mendes believed that, as a native of Padua where congregations of Ashkenazic, Sephardic, and Italian rites coexisted in one ghetto, Luzzatto had encountered a precedent or could offer religious insight. Some seventeen years passed, during which co-chief rabbis David Israel Athias and Isaac Hayim Abendana de Britto died, before Israel addressed ramifications of ritualistic differences. Perhaps Israel felt compelled to do so by a recent objection to cross-ritual acceptance. Hayim Yosef David Azulai, the prolific legalist and kabbalist who visited Amsterdam in the 1750s, ruled in a book published posthumously that Sephardim called to the Torah in Ashkenazic synagogues should refrain from reciting a blessing. ${ }^{46}$ Neither Azulai nor Israel cited each other, so it is impossible to know whether they were in dialogue, or even whether Azulai levied such a ruling in response to something he observed in Amsterdam. Nevertheless, Israel's validation of joint Ashkenazic-Sephardic prayer services may have emerged from his awareness that rituals evolvedspecifically, that Portuguese Jewry had amended the spelling of daka in their Torah scrolls - and that rabbinic authority would not successfully stem the tide of cultural melding.

Despite Israel's conviction and facility, his pesak seems to have carried no weight beyond Western Sephardic culture. ${ }^{47}$ In the halakhic record, it appears that his essay proved irrelevant. It is not that subsequent authorities disputed or disregarded Israel's opinion; rather, his ruling simply failed to germinate through citations in other rabbinic writings. The reasons for this may have rested on the scarcity of the ephemeral journal format, with few copies surviving and no publisher choosing to reprint the pesakim of Peri Ets Hayim. Moreover, the authors were rarely well-known, and content persuasively argued did not often lead to significant reception without an established rabbinic name or

46 Hayim Yosef David Azulai, Le-David Emet (Livorno, 1820), 11:16.

47 According to Mordechai Glatzer, a Pentateuch published in Amsterdam in 1764 noted for the first time in print that Sephardim spelled daka with a heh and Ashkenazim employed an alef (Glatzer, "The Massora between East and West," 169). 
title behind it. In addition, although Amsterdam itself facilitated intellectual and religious collaboration during Israel's tenure, shifting cultural centers to Eastern Europe in the latter half of the eighteenth century left Portuguese rabbinic scholarship geographically and culturally isolated.

Still, Israel's pesak proved to be surprisingly prescient. Nineteenth- and twentieth-century halakhic works increasingly addressed ritual disparity, as Jews of diverse origins crossed paths in Europe, the Americas, and the State of Israel. In the latter half of the twentieth century, Hakham Ovadia Yosef, the most influential Sephardic halakhist in modern times, ruled that Ashkenazim and Sephardim could freely recite blessings over each other's Torah scrolls. ${ }^{48}$ This latter fact signals a need for further research into Western Sephardic halakha, and beckons questions about how socio-religious circumstances of eighteenth-century Amsterdam foreshadowed Jewish experiences in the modern period.

\section{Bibliography}

Amsterdam, Archive of the Portuguese-Jewish Community, 334.

Amsterdam, Bibliotheca Rosenthaliana, Special Collections of the University of Amsterdam, HS Ros. 579 .

Amsterdam, Ets Haim/Montezinos Livraria (Ets Haim Library), 47B3.

Amsterdam, Portuguese Synagogue, T29, T45, T57, T66.

Azulai, Hayim Yosef David. Le-David Emet (Livorno, 1820).

Berkovitz, Jay R. "The Persona of a Poseq: Law and Self-Fashioning in SeventeenthCentury Ashkenaz." Modern Judaism 32, no. 3 (2012): 251-69.

Bodian, Miriam. The Hebrews of the Portuguese Nation: Conversos and Community in Early Modern Amsterdam. Bloomington: Indiana University Press, 1997.

Bonfil, Robert. Rabbis and Jewish Communities in Renaissance Italy. Translated by Jonathan Chipman. Oxford: Littman Library of Jewish Civilization, 1990.

Carlebach, Elisheva. Pursuit of Heresy: Rabbi Moses Hagiz and the Sabbatian Controversies. New York: Columbia University Press, 1990.

Fram, Edward. Ideals Face Reality: Jewish Law and Life in Poland 1550-1655. Cincinnati: Hebrew Union College Press, 1997.

Glatzer, Mordechai. "The Massora between East and West." [Hebrew] Pe'amim: Studies in Oriental Jewry 92 (2002): 167-74.

48 Ovadia Yosef, Yehaveh Da'at 2:3.19; and Yabia Omer 8, Yoreh De'ah 25. Although Yosef's halakhic writings may be best defined by their encyclopedic nature, even he did not cite Israel's pesak. 
Glick, Shmuel, ed. Seride Teshuvot of the Ottoman Empire Sages from the Cairo Genizah Collection of the Cambridge University Library. [Hebrew] Jerusalem: The Schocken Institute for Jewish Research of the Jewish Theological Seminary of America, 2013.

Goldish, Matt. Jewish Questions: Responsa on Sephardic Life in the Early Modern Period. Princeton, NJ: Princeton University Press, 2008.

Goldish, Matt. "Rabbi Jacob Sasportas: Defender of Tradition in an Age of Change." Unpublished master's thesis. Hebrew University of Jerusalem, 1990.

Hirsch, Menko Max. Frucht vom Baum des Lebens, Ozer peroth Ez Chajim. BerlinAntwerp: [Soncino-Gesellschaft der Freunde des Jüdischen Buches], 1936.

Israel, Moses. Peri Ets Hayim, (Amsterdam: Proops, 1761), EH 4F11, fols. 117r-119v.

Kahana, Maoz. "An Esoteric Path to Modernity: Rabbi Jacob Emden's Alchemical Quest." Journal of Modern Jewish Studies 12, no. 2 (2013): 253-75.

Kaplan, Yosef. An Alternative Path to Modernity: The Sephardi Diaspora in Western Europe. Leiden: Brill, 2000.

Katz, Jacob. The "Shabbes Goy": A Study in Halakhic Flexibility. Translated by Yoel Lerner. Philadelphia: Jewish Publication Society, 1989.

Katzenellenbogen, Ezekiel. Keneset Yehezkel (Altona, 1732).

Lehmann, Matthias B. Emissaries from the Holy Land: The Sephardic Diaspora and the Practice of Pan-Judaism in the Eighteenth Century. Stanford: Stanford University Press, 2014.

Levie Bernfeld, Tirtsah. Poverty and Welfare among the Portuguese Jews in Early Modern Amsterdam. Oxford: Littman Library of Jewish Civilization, 2012.

Levy, B. Barry. Fixing God's Torah: The Accuracy of the Hebrew Bible Text in Jewish Law. Oxford: Oxford University Press, 2001.

Michman, Jozeph. "Between Sephardim and Ashkenazim in Amsterdam." [Hebrew] In The Sephardi and Oriental Jewish Heritage. Edited by Issachar Ben-Ami, 135-49. Jerusalem: Magnes Press, 1982.

Ofer, Yosef. "Methods and Sources of Yedidya Shelomo Norzi in His Treatise Minhat Shay." Textus 24 (2009): 287-312.

Penkower, Jordan S. Masorah and Text Criticism in the Early Modern Mediterranean: Moshe Ibn Zabara and Menahem De Lonzano. Jerusalem: Magnes Press, 2014.

Peretz, Yossi. "Darkhe Hagahat ha-Tekst ha-Mikra'e be-Kitve Yad Ashkenazim me-Yame ha-Benayim." Talele Orot 15 (2009): 19-34.

Reiner, Elchanan. "Beyond the Realm of the Haskalah—Changing Learning Patterns in Jewish Traditional Society." Simon Dubnow Institute Yearbook 6 (2007):123-33.

Sclar, David. "Adaptation and Acceptance: Moses Hayim Luzzatto's Sojourn in Amsterdam among Portuguese Jews." Association for Jewish Studies Review 40, no. 2 (November 2016): 335-358.

Sclar, David. "Blending Tradition and Modernity: The Growth of the Ets Haim Library in the 18th Century." In Tradition \& Modernity in Ets Haim. Edited by David Wertheim, 
19-33, 38-39. Amsterdam: Menasseh Ben Israel Institute and the University of Amsterdam, 2017.

Sclar, David. "Books in the Ets Haim Yeshiva: Acquisition, Publishing, and a Community of Scholarship in Eighteenth-Century Amsterdam." Jewish History 30, no. 3 (2016): 207-32.

Soloveitchik, Haym. The Use of Responsa as an Historical Source: A Methodological Introduction. [Hebrew] Jerusalem: Zalman Shazar Center and Hebrew University of Jerusalem, 1990.

Swetschinski, Daniel. Reluctant Cosmopolitans: The Portuguese Jews of SeventeenthCentury Amsterdam. London: Littman Library of Jewish Civilization, 2000.

Zwiep, Irene E. "An Echo of Lofty Mountains: David Franco Mendes, a European Intellectual." Studia Rosenthaliana 3, no. 2 (2001): 285-96. 